\title{
SELF-ADAPTIVE ALGORITHMS FOR AN EQUILIBRIUM SPLIT PROBLEM IN HILBERT SPACES
}

\section{Wenlong Sun*, GAng Lu, YuANFEng Jin* AND ChOONKIL PARK}

Abstract. In this paper, we propose and study iterative algorithms for solving the split problem: find a common element $x^{\dagger} \in C$ satisfying

$$
\Theta\left(x^{\dagger}, y\right)+\left\langle F x^{\dagger}, y-x^{\dagger}\right\rangle+\psi\left(x^{\dagger}, y\right)-\psi\left(x^{\dagger}, x^{\dagger}\right) \geqslant 0, \forall y \in C
$$

and

$$
A u \in \operatorname{Fix}(S),
$$

where $S$ be an $L$-Lipschitzian quasi-pseudo-contractive operator. Weak and strong convergence theorems are given under some mild assumptions.

Mathematics subject classification (2020): Primary 47H06, 47H09, 49J05, 47J25. algorithm.

Keywords and phrases: Equilibrium split problem, quasi-pseudo-contractive operator, self-adaptive

\section{REFERENCES}

[1] S. H. WANG, X. M. LIU AND Y. S. AN, A new iterative algorithm for generalized split equilibrium problem in Hilbert spaces, Nonlinear Func. Anal. Appl., 22 (4) (2017), 911-924.

[2] H. H. Bauschke, Combettes, P. L. Convex Analysis and Monotone Operator Theory in Hilbert Spaces, Springer, New York, NY, USA, 2011.

[3] X. P. DING, Auxiliary principle and algorithm for mixed equilibrium problems and bilevel mixed equilibrium problems in Banach Spaces, J. Optim. Theory Appl. 146, 347-357 (2010).

[4] K. R. KAZMI, A. KhaliQ, A. RaOuf, Iterative approximation of solution of generalized mixed set-valued variational inequality problem, Math. Inequal. Appl. 10 (3), 677-691 (2007).

[5] K. R. KAZMI, S. Yousuf, Common solution to generalized mixed equilibrium problem and fixed point problems in Hilbert space, RACSAM 113, 3699-3715 (2019), https://doi.org/10.1007/s13398-019-00725-1.

[6] N. Onjai-Uea, W. Phuengrattana, On solving split mixed equilibrium problems and fixed point problems of hybrid-type multivalued mappings in Hilbert spaces, J. Inequal Appl. 2017; 2017 (1): 137, doi:10.1186/s13660-017-1416-x.

[7] E. Blum, W. Oettli, From optimization and variational inequalities to equilibrium problems, Math. Student 63 (1994) 123-145.

[8] K. Goebel, W. A. Kirk, Topics in metric fixed point theory, Cambridge: Cambridge Univ Press; 1990, (Cambridge studies in advanced mathematics).

[9] A. MoudAfI, Second order differential proximal methods for equilibrium problems, J. Inequal. Pure Appl. Math. 4 (1) (2003), Art. 18.

[10] Y. YAO, Y. J. CHO, Y. C. LiOU, Algorithms of common solutions for variational inclusions, mixed equilibrium problems and fixed point problems, European Journal of Operational Research, 2011, 212 (2): 242-250.

[11] M. A. NooR,, Auxiliary principle technique for equilibrium problems, J. Optim. Theory Appl. 122, 371-386 (2004).

[12] A. Moudafi, M. Thra, Proximal and dynamical approaches to equilibrium problems, Lecture Notes in Economics and Mathematical Systems, vol. 477, pp. 187-201, Springer, New York (1999). 
[13] A. Moudafi, Mixed equilibrium problems: Sensitivity analysis and algorithmic aspect, Comput. Math. Appl. 44, 1099-1108 (2002).

[14] D. V. HIEU, New extragradient method for a class of equilibrium problems in Hilbert spaces, Appl. Anal. 97, 811-824 (2018).

[15] D. V. HIEU, New subgradient extragradient methods for common solutions to equilibrium problems, Comput. Optim. Appl. 67, 571-594 (2017).

[16] D. V. HIEU, An extension of hybrid method without extrapolation step to equilibrium problems, J. Ind. Manag. Optim. 13, 1723-1741 (2017).

[17] D. V. HIEU, Halpern subgradient extragradient method extended to equilibrium problems, Rev. R. Acad.

[18] K. R. KAZMI, S. H. RizVI, An iterative algorithm for generalized mixed equilibrium problem, Afr. Mat. 25, 857-867 (2014).

[19] A. S. ANTIPIN, Iterative gradient predictor type methods for computing fixed point of external mappings, in: Guddat, J., Jonden, H.Th., Nizicka, F., Still, G., Twitt F. (eds.) Parametric optimization and related topics IV[C], Peter Lang, Frankfurt, Main, pp. 11-24 (1997).

[20] Q. H. ANSARI, A. REHAN, AND C. F. WEN, Implicit and explicit algorithms for split common fixed point problems, J. Nonlinear Convex Anal., 17 (2016), 1381-1397.

[21] A. E. Al-MaZrooei, A. Latif, X. Qin, et al. Fixed point algorithms for split feasibility problems, Fixed Point Theory, 2019; 20 (1): 245-254.

[22] O. A. BoiKANYO, A strongly convergent algorithm for the split common fixed point problem, Appl. Math. Comput., 265 (2015), 844-853.

[23] N. BUONG, Iterative algorithms for the multiple-sets split feasibility problem in Hilbert spaces, Numer. Algorithms 2017; 76: 783-798.

[24] Y. CENSOR, T. ElFVING, A multiprojection algorithm using Bregman projections in a product space, Numer. Algorithms 8, 221-239 (1994).

[25] Y. Censor, T. ElFVIng, N. Kopf, et al., The multiple-sets split feasibility problem and its applications for inverse problem, Inverse Probl. 2005; 21: 2071-2084.

[26] A. Cegiels KI, General method for solving the split common fixed point problem, J. Optim. Theory Appl. 2015; 165: 385-404.

[27] Y. CEnsoR, A. SEgAL, The split common fixed point problem for directed operators, J. Convex Anal. 2009; 16: 587-600.

[28] S. HE, Z. ZHAO, B. LuO, A relaxed self-adaptive CQ algorithm for the multiple-sets split feasibility problem, Optimization 2015; 64: 1907-1918.

[29] P. Kraikaew, S. Saejung, On split common fixed point problems, J. Math. Anal. Appl. 2014; 415: 513-524.

[30] P. E. MAING, Strong convergence of projected reflected gradient methods for variational inequalities, Fixed Point Theory 2018; 19: 659-680.

[31] A. MoudafI, The split common fixed-point problem for demicontractive mappings, Inverse Probl. 2010; 26: 055007.

[32] W. TAKAHASHI, The split common fixed point problem and strong convegence theorems by hybrid methods in two Banach spaces, J. Nonlinear Convex Anal. 2016; 17: 1051-1067.

[33] W. Takahashi, C. F. Wen, J. C. YaO, An implicit algorithm for the split common fixed point problem in Hilbert spaces and applications, Appl. Anal. Optim. 2017; 1: 423-439.

[34] F. WANG, A new method for split common fixed-point problem without priori knowledge of operator norms, J. Fixed Point Theory Appl., doi:10.1007/s11784-017-0434-0.

[35] H. K. XU, Iterative algorithms for nonlinear operators, J. Lond. Math. Soc. 66, 240-256 (2002).

[36] Y. YAO, Y.-C. LIOU, J.-C. YAO, Split common fixed point problem for two quasi-pseudocontractive operators and its algorithm construction, Fixed Point Theory Appl. 2015, 2015, 127.

[37] Y. H. Yao, Y. C. Liou, M. Postolache, Self-adaptive algorithms for the split problem of the demicontractive operators, Optimization 2018; 67: 1309-1319.

[38] Y. H. YAO, Y. C. YAO, Y. C. LiOU, et al., Iterative algorithms for split common fixed points of demicontractive operators without priori knowledge of operator norms, Carpathian J. Math. 2018; 34: 459-466. 